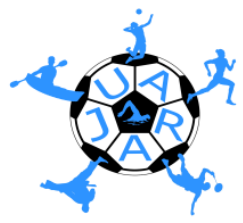

JUARA: Jurnal Olahraga

E-ISSN 2655-1896 ISSN 2443-1117

https://doi.org/10.33222/juara.v6i1.1164

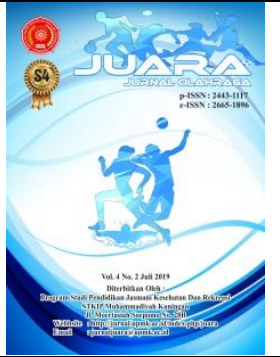

\title{
Students's Academic Level Stress During Online Learning in Physical Education
}

\author{
Gita Febria Friskawati
}

Department of Physical Education, STKIP Pasundan, Street Permana No.32B, Citeureup, City of Cimahi, West Java 40512, Indonesia

email: gita032@gmail.com

\section{Article Info}

Article History.

Received 20 November 2020

Approved 02 January 2021

Published 22 January 2021

Keywords:

Stress Academic Level,

Online Learning,

Physical Education

\begin{abstract}
Changes in online learning, especially in physical education learning, make students feel pressured by the teacher's assignments. This study aims to reveal students' level of academic stress at each level, starting from elementary, junior high, and high school students when doing online learning of physical education. Survey research was used to uncover this problem. The population consisted of 76 elementary students, 88 junior high school students, and 81 high school students scattered in Cimahi City. Taking the camp, they were taking convenience sampling technique. The Stress Reaction Checklist (SRCL) instrument was used to measure students' academic stress levels. The calculation uses simple percentage descriptive analysis. The results show that academic stress levels are different at each level of SD, SMP, and SMA in facing online physical education learning. Middle school and high school students have the highest academic stress levels, while elementary students are at medium stress academic levels. There is a need for collaboration between teachers and parents to familiarize students with online learning during the Covid-19 pandemic, although learning with this will not last forever.
\end{abstract}

(C) 2021 Gita Febria Friskawati Under the license CC BY-SA 4.0

\footnotetext{
$凶$ Alamat korespondensi: Street Permana No.32B, Citeureup, City of Cimahi

E-mail_: gita032@gmail.com
}

\section{INTRODUCTION}

implementation of education in schools is

The Covid 19 pandemic limits all activities carried out by humans (Keptner \& Mccarthy, 2020), including education provision (Moawad, 2020). This is done to prevent the spread of Covid 19 in the school environment (WHO, 2020). The directed at online learning from home (WHO, 2020). Likewise, physical education, which should require space and collaboration with other friends in learning (Østergaard, 2018), is forced to change the learning model from face to face to online. 
During this pandemic, educational activities include distance learning using gadget media, the internet, video conferencing, and two-way live streaming. The Covid 19 pandemic urges testing of distance education that has never been done simultaneously before (Macintyre, Gregersen, \& Mercer, 2020) for all education elements, namely students, teachers, to parents. Given that during a pandemic, time, location, and distance are big problems today (Poudel, 2020).

Although physical education can be done online from home and contributes to increasing body immunity because of the movement activities carried out (Yousfi et al., 2020), some of the negative impacts of online learning on physical education have been revealed. The time for presenting the material lacks (Mahapatra, 2020) so that students learn one material provided by the teacher. Giving feedback and student motivation are also rarely given by teachers (Mishra, Gupta, \& Shree, 2020) to impact sub-optimal mastery of the material ( $\mathrm{Pal} \&$ Vanijja, 2020). The psychological impact of organizing online learning is also felt by students (Sifat, 2020). The study found that the highest presentation was students' stress when online education was carried out (Moawad, 2020). The mismatch of expectations for student learning, such as the teacher's many tasks, is one of the triggers for student stress when learning online (Vanslambrouck et al., 2019).

In a survey conducted by KPAI, as many as $79.9 \%$ of children thought that interaction was reduced and the teacher only gave heavy tasks so that children experienced increased stress, and $20.1 \%$ did not know there was interaction in the learning process (Hasanah, 2020). The negative impact of the existence of regulations such as Social \& Physical Distancing and PSBB, children feel their souls become more depressed because they continue to carry out all activities, including learning from home (Purwanto, 2020).

Academic stressors that often trigger students in online learning are inadequate learning facilities $(40.7 \%)$, learning difficulties for an extended period (32.5\%), too many assignments, and academic load (23.5\%). \%), (Yikealo, Tareke, \& Karvinen, 2018). During the Covid 19 pandemic, students experienced stress, and mental stress conditions also caused physical stress. Another study states that there are ten symptoms or health problems, including fatigue $(24.4 \%)$, decreased appetite $(10.6 \%)$, back pain and digestive issues (9.8\%), fever (7.3\%). Insomnia (5.8\%), urinary system $(4.9 \%)$, headache and heart rate increases $(4.1 \%)$, and respiratory system problems (3.3\%) (Poudel, 2020).

The state of students at moderate to severe stress levels can hinder learning (Amin, 2018). Increasing the amount of academic stress will decrease academic ability, which will impact the student achievement index (Shorer \& Leibovich, 2020). Other studies have shown that students evaluated during the pandemic period exhibit significantly higher anxiety, depression, and stress than students 
during regular times (Wang, Zhao, \& Maia, 2020).

Based on previous research, stress both mentally and physically occurs a lot among students who are undergoing online schooling, especially in physical education subjects; it is necessary to conduct research to know the description of student stress levels at each school level starting from elementary junior high school. And SMA in the online learning process during the Covid-19 pandemic through quantitative research.

\section{METHODS}

The survey research method was carried out to reveal students' stress levels at the elementary, middle, and high school levels in facing online physical education learning. The population consisted of 76 elementary students, 88 junior high school students, and 81 high school students scattered in Cimahi City. They were taking the sample using the convenience sampling technique. The Stress Reaction Checklist (SRCL) instrument from (Shorer \& Leibovich, 2020) was used in this study to measure students' stress levels. Descriptive analysis is used to reveal this research.

\section{FINDINGS AND DISCUSSION}

\section{Findings}

The data from the distribution of academic stress questionnaires were processed using descriptive analysis with SPSS 19. This data is a combination of data acquisition from academic stress at the SD, SMP, and SMA levels. Table 1 presents a summary of the calculated frequency of the academic stress variables.

Table 1. Frequency distribution of academic stress

\begin{tabular}{lcccc}
\hline \multirow{2}{*}{\begin{tabular}{l} 
Academic Stress Components \\
\cline { 2 - 5 }
\end{tabular}} & Never & Doubt & Often & Frequency \\
\cline { 2 - 5 } & & $\%$ & $\%$ & $\%$ \\
\hline Biased assessment of learning outcomes & 12.50 & 24.40 & 29.60 & 11.30 \\
Emphasis on everyday learning online. & 29.30 & 16.30 & 40.40 & 20.60 \\
It is difficult to follow online learning. & 10.10 & 24.40 & 28.50 & 16.70 \\
It is difficult to study online for a long time. & & 22.00 & 20.30 & 18.60 \\
Too many assignments given. & 5.80 & 6.50 & 45.70 & 41.50 \\
There are no networks that support online learning. & 7.20 & 10.70 & 40.70 & 30.10 \\
Monotonous material delivery. & 11.00 & 24.05 & 17.90 & 10.40 \\
Boredom while studying online every day. & 12.40 & 22.10 & 35.50 & 25.30 \\
\hline
\end{tabular}

The research data in table 1 shows that the acquisition of the highest overall frequency of stress academic scores from the calculation shows that too many assignments are 41.50, followed by an unavailable network of 30.10 and boredom while studying online at 25.30.
Furthermore, the data is processed again to see the level of academic stress at each school level starting from SD, SMP, and SMA, presented in table. 2. 
Table 2. Percentage of Academic Stress Level

\begin{tabular}{lcccccc}
\hline & \multicolumn{5}{c}{ School Level } \\
\cline { 2 - 7 } Academic & \multicolumn{2}{c}{ SD } & \multicolumn{2}{c}{ SMP } & \multicolumn{2}{c}{ SMA } \\
Stress & \multicolumn{2}{c}{$n=76$} & \multicolumn{2}{c}{$n=88$} & \multicolumn{2}{c}{$n=81$} \\
\cline { 2 - 7 } \multicolumn{1}{c}{ Level } & Freq. & $\%$ & Freq & $\%$ & Freq & $\%$ \\
& & & & &. & \\
\hline Low & 26 & 27 & 20 & 16 & 17 & 13 \\
Moderate & 29 & 52 & 30 & 23 & 23 & 20 \\
High & 19 & 21 & 38 & 61 & 41 & 67 \\
Total & 74 & 100 & 88 & 100 & 81 & 100 \\
\hline
\end{tabular}

The calculations in table 2. Show that the academic stress level for elementary students is at a moderate level with a frequency value of 29 and a percentage of $52 \%$, for junior high school students at a high level with a frequency value of 30 and a rate of $61 \%$, high school students at a high-level frequency of 41 and the percentage of $67 \%$.

\section{Discussion}

The results showed that most junior and senior high school levels had high academic stress levels. Many factors can cause the educational group of stress students feel while studying (Amin, 2018; Fatkhul et al., 2020; Gutowski, White, Liang, Diamonti, \& Berado, 2017).. Previous research revealed that most of the high levels of academic stress in junior and senior high school students during learning were caused by learning with an online system (Macintyre et al., 2020). The academic stressors that are most often revealed are student preparation for exams (Mahfouz, 2018), competence in getting good grades, and mastery of material that must be caught quickly at every meeting (Dolfen, King, Schwabe, Swinnen, \& Albouy, 2019) and learning media factors which is considered unsuitable for them, (Yikealo et al., 2018).
The level of academic stress in students has increased with online learning during the Covid 19 pandemic (Shorer \& Leibovich, 2020). The dissemination of learning during a pandemic through digital portals will require access to laptops/computers and gadgets for students (Polizzi, 2020). Considering the gap between students' different socioeconomic strata (UNESCO, 2020), this will trigger stress learning online for students. (Barlow, Sepulveda, \& Barlow, 2020). Academic stress at a high level is closely related to student learning motivation and student involvement in the learning process (Liu, 2015).

Other studies have suggested that COVID-19-related stressors, which include economic stress, daily life effects, and academic delay, are positively associated with student anxiety symptoms during a pandemic (Cao et al., 2020). Students' feeling of pressure when facing instructional assignments given online, and the time limit, which tends to be narrow, makes students feel stressed (Shorer \& Leibovich, 2020). Most students lack technical resources, high internet costs, low internet speeds, family financial instability, and mental stress. Students are the most significant stressors in facing online learning (Sifat, 2020). 
Staying at home usually makes students mentally depressed. Students who feel mentally stressed refuse to take online classes or don't want to participate in online courses. Approximately $43 \%$ of middle students experience mental stress, anxiety and cannot attend the online class format (Ramij, 2020). Especially in Physical Education learning, most of the teacher's tasks are making motion videos that must be sent back to the teacher (Komarudin, 2020), so this activity requires adequate signal quality and internet. The results of other research show that $35 \%$ of respondents as school students state that the cause of student stress when learning physical education online is due to not being able to apply practical learning due to the unavailability of tools around the house (D, Luiz, Teixeira, Roberto, \& Silva, 2020).

This study also revealed that the academic stress of elementary school students was lower than junior and senior high school students. The academic stress level of elementary school students is at a moderate level. Online schooling activities for elementary students, especially in physical education learning, are accompanied by their parents' assistance (Herlina, 2020). The characteristics of elementary students who do not fully own and operate their devices properly are one reason to be fully supported by parents when studying online (Aji, Dewi, Kristen, \& Wacana, 2020). This makes elementary school students' levels still at a reasonable level when facing online learning (Hasanah, 2020). Research shows that parents who have children in the pre-school to elementary school age range show a high level of stress when learning online from home than their children who go to school at a low-stress level (Susilowati et al., 2020).

The shift in student learning culture from face-to-face to online learning is also troubling for them (Fatkhul et al., 2020). When going to school, especially in the physical education learning process, which is carried out in an open field, students are used to interacting, playing, and joking with their friends. This activity will reduce the burden on students in facing learning and tasks that must be completed by them (Gutowski et al., 2017). By discussing with their peers, at least they can reduce the stress they feel (Mahfouz, 2018).

Therefore, it is necessary to have time for school students at all levels to be able to adapt to learning methods that are considered new for them to adapt and deal with these new changes, which indirectly affect stress levels when learning online, which will have an impact on their learning absorption. (Pal \& Vanijja, 2020). For elementary students, the use of devices that is not optimal requires them to be fully accompanied by their parents so that the online learning process, especially physical education learning, can be carried out well (Brien et al., 2020). Online learning strategies in physical education to adapt new habits are recommended for further research so that students are not easily stressed. 


\section{CONCLUSION}

Changes in online learning, especially in physical education learning, make students not ready to face it. Students feel many negative impacts, one of which is experiencing academic stress because changes in learning culture occur very quickly, and students are not ready to accept it. The results showed that the level of academic stress was different at each level of SD, SMP, and SMA in the face of online Physical Education learning. Middle school and high school students have the highest academic stress levels, while elementary students are at medium stress academic levels.

There is a need for collaboration between teachers and parents to familiarize students with online learning during the Covid 19 pandemic, although learning with this will not last forever..

\section{AKNOWLEDGMENTS}

The author would like to thank the Head of STKIP Pasundan and MGMP of the Cimahi Branch of Physical Education, who have facilitated and supported this research.

\section{REFERENCES}

Aji, W., Dewi, F., Kristen, U., \& Wacana, S. (2020). Dampak Covid-19 Terhadap Implementasi Pembelajaran Daring Di, 2(1), 55-61.

Amin, F. (2018). Online Reputation and Stress: Discovering the Dark Side of Social Media. https://doi.org/10.1177/23197145209481 71

Barlow, K., Sepulveda, A. A., \& Barlow, K. (2020). World Federation of Occupational Therapists Bulletin The promotion of positive mental health for new mothers during Covid-19 The promotion of positive mental health for new mothers during Covid-19. World Federation of Occupational Therapists Bulletin, $\quad 0(0), \quad 1-4$. https://doi.org/10.1080/14473828.2020.1 822577

Brien, W. O., Adamakis, M., Brien, N. O., Onofre, M., Dania, A., Makopoulou, K., ... Costa, J. (2020). Implications for European Physical Education Teacher Education during the COVID-19 pandemic: a cross-institutional SWOT analysis Implications for European Physical Education Teacher crossinstitutional SWOT analysis. European Journal of Teacher Education, 00(00), 120.

https://doi.org/10.1080/02619768.2020.1 823963

Cao, W., Fang, Z., Hou, G., Han, M., Xu, X., \& Dong, J. (2020). The psychological impact of the COVID-19 epidemic on college students in China. Psychiatry Research, 287(March), 112934. https://doi.org/10.1016/j.psychres.2020.1 12934

D, E. S., Luiz, A., Teixeira, S., Roberto, J., \& Silva, D. (2020). Physical education role during coronavirus disease 2019 ( 
COVID-19 ) pandemic Physical education and COVID-19, 2019, 20192020.

Dolfen, N., King, B. R., Schwabe, L., Swinnen, S., \& Albouy, G. (2019). Neurobiology of Learning and Memory Glucocorticoid response to stress induction prior to learning is negatively related to subsequent motor memory consolidation. Neurobiology of Learning and Memory, 158(December 2018), 32 41.

https://doi.org/10.1016/j.nlm.2019.01.00 9

Fatkhul, M., Basthomi, Y., Tengah, J., Semarang, U. M., Semarang, K., Tengah, J., ... Timur, J. (2020). “ tugas pembelajaran " penyebab stres mahasiswa selama pandemi covid-19, 3(2), 203-208.

Gutowski, E., White, A. E., Liang, B., Diamonti, A., \& Berado, D. (2017). How Stress Influences Purpose Development: The Importance of Social Support. https://doi.org/10.1177/07435584177377 54

Hasanah. (2020). Gambaran psikologis mahasiswa dalam proses pembelajaran selama pandemi covid-19, 8(3), 299-306.

Herlina. (2020). Potensi Pembelajaran Pendidikan Jasmani Olahraga Dan Kesehatan ( Pjok ) Di Tengah Pandemi Corona Virus Disease ( COVID ) -19 Di Sekolah Dasar, 0383.

Keptner, K. M., \& Mccarthy, K. (2020). World Federation of Occupational Therapists
Bulletin Disruption of academic occupations during COVID-19: impact on mental health and the role of occupational therapy in tertiary education and the role of occupational therapy in tertiary education. World Federation of Occupational Therapists Bulletin, O(0), $1-4$.

https://doi.org/10.1080/14473828.2020.1 822575

Komarudin. (2020). Available online at https://journal.uny.ac.id/index.php/major a, 26(2), 56-66.

Liu, Y. (2015). The Chinese high school student, $\mathrm{s}$ stress in the school and academic achievement, (931923715). https://doi.org/10.1080/01443410.2010.5 13959

Macintyre, P. D., Gregersen, T., \& Mercer, S. (2020). Language teachers coping strategies during the Covid-19 conversion to online teaching: Correlations with stress, wellbeing and negative emotions. System, 94, 102352. https://doi.org/10.1016/j.system.2020.10 2352

Mahapatra, A. (2020). Education in times of COVID-19 pandemic: Academic stress and its psychosocial impact on children and adolescents in India, 10-12. https://doi.org/10.1177/00207640209618 01

Mahfouz, J. (2018). Principals and stress : Few coping strategies for abundant stressors. https://doi.org/10.1177/17411432188175 62 
Mishra, L., Gupta, T., \& Shree, A. (2020). Online Teaching-Learning in Higher Education during Lockdown Period. International Journal of Educational Research Open, 100012. https://doi.org/10.1016/j.ijedro.2020.100 012

Moawad, R. A. (2020). Online Learning during the COVID- 19 Pandemic and Academic Stress in University Students, (June).

https://doi.org/10.18662/rrem/12.1sup2

Østergaard, L. D. (2018). Creation of new routines in physical education: secondorder reflection as a tradition-challenging form of reflection stimulated by inquirybased learning. Sport, Education and Society, $\quad 0(0), \quad 1-13$. https://doi.org/10.1080/13573322.2018.1 508012

Pal, D., \& Vanijja, V. (2020). Vajirasak Vanijja Article Title : Perceived Usability Evaluation of Microsoft Teams as an Online Learning Platform During COVID-19 using System Usability Scale and Technology Acceptance Model in India Corresponding author details: Postal address: School. Children and Youth Services Review, 105535. https://doi.org/10.1016/j.childyouth.2020 .105535

Polizzi, G. (2020). Computers \& Education Digital literacy and the national curriculum for England: Learning from how the experts engage with and evaluate online content. Computers \&
Education, 152(April 2019), 103859. https://doi.org/10.1016/j.compedu.2020.1 03859

Poudel, K. (2020). Impact of COVID-19 pandemic on socioeconomic and mental health aspects in Nepal. https://doi.org/10.1177/00207640209422 47

Purwanto, A. (2020). Studi Eksploratif Dampak Pandemi COVID-19 Terhadap Proses Pembelajaran Studi Eksploratif Dampak Pandemi COVID-19 Terhadap Proses Pembelajaran Online di Sekolah Dasar, (April).

Ramij, G. (2020). Preparedness of Online Classes in Developing Countries amid COVID-19 Outbreak: A Perspective from Bangladesh.

Shorer, M., \& Leibovich, L. (2020). Young children' $\mathrm{s}$ emotional stress reactions during the COVID-19 outbreak and their associations with parental emotion regulation and parental playfulness. Early Child Development and Care, $\mathrm{O}(0)$, $1-11$.

https://doi.org/10.1080/03004430.2020.1 806830

Sifat, R. I. (2020). COVID-19 pandemic: Mental stress, depression, anxiety among the university students in Bangladesh, 65-66. https://doi.org/10.1177/00207640209659 95

Susilowati, E., Kesejahteraan, P., Bandung, S., Azzasyofia, M., Tinggi, S., \& Sosial, K. (2020). The Parents Stress Level in 
Facing Children Study From Home in the Early of Covid-19 Pandemic in Indonesia, (April).

UNESCO. (2020). Policy Brief: Education during COVID-19 and beyond, (August).

Vanslambrouck, S., Zhu, C., Pynoo, B., Lombaerts, K., Tondeur, J., \& Scherer, R. (2019). Computers in Human Behavior A latent profile analysis of adult students ' online self-regulation in blended learning environments. Computers in Human Behavior, 99(May), 126-136. https://doi.org/10.1016/j.chb.2019.05.021 Wang, C., Zhao, H., \& Maia, B. R. (2020). The Impact of COVID-19 on Anxiety in Chinese University Students, 11(May), $1-8$.

https://doi.org/10.3389/fpsyg.2020.01168
WHO. (2020). COVID-19 Education in the time of COVID-19, (August).

Yikealo, D., Tareke, W., \& Karvinen, I. (2018). The Level of Stress among College Students : A Case in the College of Education, Eritrea Institute of Technology Abstract:, (November), 118.

Yousfi, A. N., Bragazzi, N. L., Briki, W., Zmijewski, P., \& Chamari, K. (2020). the quarantine - a multidisciplinary approach with special focus on athletes. The COVID-19 pandemic : how to maintain a healthy immune system during the lockdown - a multidisciplinary approach with special focus on athletes, (May). https://doi.org/10.5114/biolsport.2020.95 125 